\title{
Urease activity and its relationships to soil physiochemical properties in a highly saline-sodic soil
}

\author{
T. Zhang ${ }^{1,2}$, S. Wan ${ }^{3}$, Y. Kang ${ }^{3 *}$, H. Feng ${ }^{1,2}$
}

\begin{abstract}
${ }^{1}$ Institute of Soil and Water Conservation, Northwest A\&F University Yangling 712100, Shaanxi, China. ${ }^{2}$ Institute of Soil and Water Conservation, Chinese Academy of Sciences \& Ministry of Water Resources, Yangling 712100, Shaanxi, China. ${ }^{3}$ Key Laboratory of Water Cycle and Related Land Surface Processes, Institute of Geographic Sciences and Natural Resources Research, Chinese Academy of Sciences, Beijing 100101, China. Corresponding author: kangyh@igsnrr.ac.cn
\end{abstract}

\begin{abstract}
To ascertain the levels of urease activities (UA) and their relationships with soil physicochemical properties in salt-affected soils during reclamation, soil transects of a saline-sodic soil with different planting years under drip irrigation were intensively sampled. An enhanced soil UA in root zone (0-40 $\mathrm{cm}$ beneath drip emitter) was found as the planting years increased. In all transects, soil UA ranged from 0.38 to $8.53 \mu \mathrm{g} \mathrm{NH}_{4}^{+}-\mathrm{N}$ released g-1 dry soil $\mathrm{h}^{-1}$ at $37^{\circ} \mathrm{C}$, and showed a large spatial variability within transect. $\mathrm{R}^{2}$ of multiple regressions increased gradually with planting years, indicating that variations in UA could be better predicted after amelioration. Path analysis showed that the negative direct effects of soil $\mathrm{pH}$ on UA were clearly dominant, with the direct path coefficients of $-0.357 \sim-0.666(p<0.05)$. Soil organic matter yielded greater positive indirect path coefficients through $\mathrm{pH}$ and total nitrogen. An exponential relationship was found between soil UA and $\mathrm{pH}$ values $(p<0.01)$. Our findings demonstrate that after the cultivation under drip irrigation for 3 years, soil biological activities and fertility level increased, with the decrease of soil salinity and sodicity.
\end{abstract}

Keywords: Soil enzyme, wolfberry, takyric solonetz, drip irrigation, path analysis

\section{Introduction}

Large area of salt-affected wasteland, covering about $1 \times 10^{9}$ ha area of the world, restricts the crop production in arid/semi-arid regions of the world (Abrol et al., 1988). Under different categories of saltaffected soils, sodic and saline-sodic soils constitute about $60 \%$ of the world's salt-affected area (Qadir et al., 2001). A highly saline-sodic soil, classified as takyric solonetz (IUSS Working Group WRB, 2007), covers about $2.3 \times 10^{4}$ ha of Ningxia Plain, northwest China (Wang, 1990). The soil is characterized by the occurrence of extremely excessive sodium (ESP of $15-60$ or even $>90$ at some locations and $\mathrm{pH}$ of 9-10), which leads to deterioration of soil structure. This soil does not support any vegetation except some bluegreen algae, such as microcoleus, growing in patches during the monsoon season (Wang et al., 1993). 
In the recent decades, many methods have been attempted to reclaim the saline-sodic soil. They included deep ploughing, application of organic fertilizer, rice cropping along with frequent irrigation and drainage, replacement of the entire surface soil with a good soil, and use of gypsum (Wang et al., 1993). However, many methods were not effective primarily because of the very low saturated hydraulic conductivities of the soil in Ningxia Plain $\left(\mathrm{K}_{\mathrm{s}}<0.1\right.$ mm/d) (Wang, 1990; Wang et al., 1993), or were thwarted by the long amelioration period and the high costs involved.

With precise application of water and nutrients, drip irrigation has been used widely to reclaim many saltaffected soils in recent years, including some salinesodic soils (Hanson and May, 2003; Burt and Isbell, 2005; Liu et al., 2011). In 2009, drip irrigation was adopted on this highly saline-sodic soil in Ningxia Plain for cropping wolfberry (Lycium barbarum L.), and considerable reclamation was achieved: an improved soil water-salt environment for crop growth was formed, and the fruit yield after planting 3 years reached the level of local farmland (Zhang et al., 2013).

Due to the sensitivity to the environmental changes, soil enzymes activities have been proposed to evaluate the sustainability and economic effects of agricultural practices, and even to diagnose the soil categories (Garcia et al., 1997; Tripathi et al., 2006). Among many soil enzymes, urease (urea amidohydrolase, EC 3.5.1.5), closely associated with the transformation, biological turnover and bioavailability of nitrogen (Liang et al., 2003; Yuan et al., 1997), is a key enzyme. Meanwhile, since the relationship between increased salinity (or/and sodicity) and reduced UA appears to be highly predictable, it was suggested that the changes in UA could be developed into a sensitive and early indicator of soil quality (Sinsabaugh, 1994; Cookson and Lepiece, 1996). So it is helpful and necessary to predict UA level for the subsequent fertilizer management during the land utilization. However, the studies about the changes in UA during the reclamation of the saline-sodic soils with drip irrigation is absent until now.

The objectives of the present study were, (1) to determine the changes of UA in saline-sodic soils with different planting years under drip irrigation and the spatial distribution of UA in fine scales around individual wolfberry, and (2) to compare the relative importance of soil salinity and sodicity, as well as nutrient concentrations in predicting UA.

\section{Materials and Methods}

\subsection{Study site}

The study was undertaken in Xidatan Agricultural Comprehensive Development Experimental Station (latitude $38^{\circ} 52^{\prime} \mathrm{N}$; longitude, $106^{\circ} 27^{\prime} \mathrm{E}$; altitude $1095 \mathrm{~m}$ ), Pingluo County, Ningxia Hui Autonomous Region, northwest China. Located in the floodplain area on the east side of Helanshan Montain, and the north of Ningxia Plain, the station has a typical arid continental climate, with a mean annual temperature of $9.4{ }^{\circ} \mathrm{C}$, and an average annual rainfall of $178 \mathrm{~mm}$. The annual potential evaporation is $>2000 \mathrm{~mm}$. The average water table is at a depth of $\sim 2.5 \mathrm{~m}$.

A highly saline-sodic wasteland exists in the area. Developed in alluvial deposits, the experimental soil is classified as takyric solonetz (IUSS Working Group WRB, 2007), which is widespread in semi-arid and semi-desert saline regions. With the homogeneous soil structure and properties, the soil in this area does not support any vegetation except some bluegreen algae, such as microcoleus growing in patches during the monsoon season. The average soil $\mathrm{EC}_{\mathrm{e}}, \mathrm{pH}$ and SAR in $0-30 \mathrm{~cm}^{-}$were $12.3 \mathrm{dS} \mathrm{m}^{-1}, 9.4$ and 44.1 $\left.(\mathrm{mmol} \mathrm{L})^{-1}\right)^{0.5}$, respectively. The other detailed soil properties in the uncultivated soil profile are depicted in Table 1. 
Table 1. Soil UA and main physicochemical properties in uncultivated soil.

\begin{tabular}{cccccccccc}
\hline $\begin{array}{c}\text { Soil depth } \\
(\mathrm{cm})\end{array}$ & $\begin{array}{c}\mathrm{UA} \\
\left(\mu \mathrm{g} \mathrm{g}^{-1} \mathrm{~h}^{-1}\right)\end{array}$ & $\begin{array}{c}\text { Moisture } \\
(\%)\end{array}$ & $\begin{array}{c}\mathrm{EC}_{\mathrm{e}} \\
\left(\mathrm{dS} \mathrm{m}^{-1}\right)\end{array}$ & $\mathrm{pH}$ & $\begin{array}{c}\mathrm{SAR} \\
\left(\mathrm{mmol} \mathrm{L}^{-1}\right)^{0.5}\end{array}$ & $\begin{array}{c}\mathrm{TN} \\
\left(\mathrm{g} \mathrm{kg}^{-1}\right)\end{array}$ & $\begin{array}{c}\mathrm{TP} \\
\left(\mathrm{g} \mathrm{kg}^{-1}\right)\end{array}$ & $\begin{array}{c}\mathrm{OM} \\
\left(\mathrm{g} \mathrm{kg}^{-1}\right)\end{array}$ & $\mathrm{C} / \mathrm{N}$ \\
\hline $0-10$ & 1.49 & 7.64 & 18.54 & 8.90 & 39.76 & 0.23 & 0.74 & 6.28 & 13.88 \\
$10-20$ & 1.67 & 9.44 & 11.66 & 9.58 & 54.01 & 0.39 & 0.74 & 6.79 & 8.43 \\
$20-30$ & 1.78 & 10.51 & 6.69 & 9.52 & 38.59 & 0.24 & 0.73 & 6.56 & 11.08 \\
$30-40$ & 1.71 & 11.70 & 4.16 & 9.51 & 23.15 & 0.36 & 0.57 & 6.39 & 6.92 \\
$40-60$ & 2.26 & 13.61 & 2.45 & 9.50 & 15.43 & 0.37 & 0.64 & 4.00 & 7.38 \\
$60-80$ & 1.68 & 11.27 & 1.89 & 9.43 & 7.72 & 0.31 & 0.65 & 4.32 & 9.46 \\
$80-100$ & 1.57 & 11.20 & 1.67 & 9.24 & 7.72 & 0.28 & 0.58 & 2.04 & 9.43 \\
\hline
\end{tabular}

UA, urease activities; ECe, electrical conductivity of saturated paste extract; $\mathrm{pH}, \mathrm{pH}$ value of saturated paste; SAR, sodium adsorption ratio of the saturated paste extract; TN, total nitrogen; TP, total phosphorus; OM, organic matter; $\mathrm{C} / \mathrm{N}$, ratio of organic carbon-to-total nitrogen.

\subsection{Agronomy practices}

In April 2009, a plot of the highly saline-sodic wasteland was reclaimed for cropping wolfberry (Lycium. barbarum L.) with ridge culture under drip irrigation. The ridge was constructed with a height of $0.5 \mathrm{~m}$, a width of $1 \mathrm{~m}$, and $3 \mathrm{~m}$ between ridge centers (Figure 1). Drip irrigation tapes with an emitter spacing of $0.2 \mathrm{~m}$ and a flow rate of $0.76 \mathrm{~L} / \mathrm{h}$ at an operating pressure of $0.03 \mathrm{MPa}$, were placed onto the center of each raised bed. Wolfberry (cultivars: Ningqi No. 1) seedlings were transplanted into the center of the beds at intervals of $1 \mathrm{~m}$ and the ridges were mulched with white polyethylene film (Figure 1). Irrigation was triggered by controlling the soil matric potential, measured at depth of $0.2 \mathrm{~m}$ beneath the drip emitter, higher than $-15 \mathrm{kPa}$ (Zhang et al., 2013). Urea, phosphoric acid and potassium nitrate were dissolved and applied with the irrigation water. The fertilizing amount was half of the corresponding level in local farmland. In the successive two years (2010 and 2011), a new plot was reclaimed with the same method in each year adjacent to the plot reclaimed in 2009.

\subsection{Soil sampling and analysis}

Soils were sampled at the end of growing season (9th October) in 2011, when there were 3 plots with different planting years, i.e. plot 1, 2 and 3, reclaimed in 2011, 2010 and 2009 respectively. Nine vertical transects perpendicular to the drip tapes in the location of the nearest drip emitter around wolfberry (3 transects per plot) were selected for soils sampling. 62 soil samples were sampled per transect with an auger (diameter, $4.0 \mathrm{~cm}$; length, $20 \mathrm{~cm}$ ), the horizontal distances of sampling points from the drip emitters were $0,10,20,30,40,60,80,100,120$ and $150 \mathrm{~cm}$, and the sampling depths were $0-10,10-20,20-30$, $30-40,40-60,60-80$ and $80-100 \mathrm{~cm}$ (Figure 1). At the same time, soils were also sampled at the depth of $0-100 \mathrm{~cm}$ in 3 uncultivated soil profiles adjacent to the studied plots.

Immediately after sampling and carefully removing the surface organic materials and fine roots, soil moisture (\%) was determined gravimetrically on the field moist subsamples. Then three replicates of the remaining subsamples from each plot were mixed into one sample. Soil transects from the plots with 1,2 and 3 planting years were labeled as transect 1 , transect 2 and transect 3 respectively, and the samples from the uncultivated soil profiles was labeled as transect 0 with 0 planting year. The remaining soil subsamples were air-dried, passed through a 1-mm sieve, and stored in closed, rigid polypropylene boxes at room temperature for less than 8 weeks before being assayed for soil physicochemical properties and UA. 


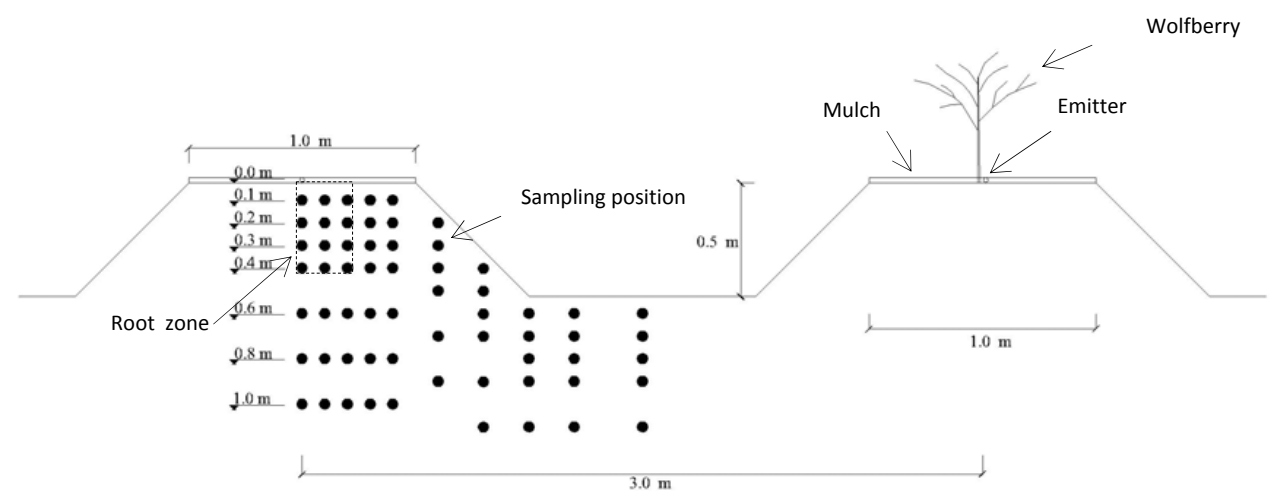

Figure 1. Vertical view of planting pattern and soil sampling positions

Saturated soil paste was prepared for the chemical analysis. The $\mathrm{pH}$ of saturated paste was measured with a pH meter (PHS-3C, Shanghai Precision \& Scientific Instrument Co., LTD. Shanghai, China). Then clear extracts of the saturated soil pastes were obtained by centrifugation (4000 rpm, $30 \mathrm{~min}$ ) and analyzed for the electrical conductivity of saturated paste extract (ECe), $\mathrm{Ca}^{2+}, \mathrm{Mg}^{2+}$ and $\mathrm{Na}+$ concentrations. ECe was measured with a conductivity meter (DDS-11A, Shanghai Precision \& Scientific Instrument Co., LTD. Shanghai, China). $\mathrm{Ca}^{2+}$ and $\mathrm{Mg}^{2+}$ were measured by an EDTA titration method, and $\mathrm{Na}^{+}$by flame photometry as described (Bao, 2000). The sodium adsorption ratio of the saturated paste extract (SAR) was calculated using the formula:

$$
\mathrm{SAR}=\frac{\left[\mathrm{Na}^{+}\right]}{\left(\left[\mathrm{Ca}^{2+}\right]+\left[\mathrm{Mg}^{2+}\right]\right)^{0.5}}
$$

where the concentration of each cation is in $\mathrm{mmol} \mathrm{L}^{-1}$.

The sieved soils were ground again to pass through a $0.15-\mathrm{mm}$ sieve for the assay of organic matter and total nutrients. Total nitrogen (TN) content was determined by Kjeldahl method. Total phosphorus (TP) was determined by plasma spectrometer after soil samples were igested with $\mathrm{HClO}_{4}$.
Soil organic matter (OM) concentration was calculated by multiplying the organic carbon (OC) concentration, measured by dichromate oxidation method, by 1.724 (Bao, 2000). The ratio of soil organic carbon-to-total nitrogen $(\mathrm{C} / \mathrm{N})$ was calculated based on soil OC and TN concentration. Soil UA, which was expressed as $\mu \mathrm{g}$ $\mathrm{NH}_{4}^{+}-\mathrm{N}$ released $\mathrm{g}^{-1}$ dry soil $\mathrm{h}^{-1}$ at $37{ }^{\circ} \mathrm{C}\left(\mu \mathrm{g} \mathrm{g}^{-1} \mathrm{~h}^{-1}\right.$ in abbreviation), was assayed spectrophotometrically by the indophenol blue method described by Guan (1986).

\subsection{Data analysis}

The root zone was defined as a section of $0-20 \mathrm{~cm}$ horizontal distance from the drip emitter and 0-40 cm at depth, the spatial weighted mean of soil UA in root zone was calculated as follows:

$$
\mathrm{UA}(i)=\frac{\sum_{\substack{j=0,10,20 \\ k=10,20,30,40}} \mathrm{UA}(i, j, k) \times \mathrm{S}(j, k)}{\sum_{\substack{j=0,10,20 \\ k=10,20,30,40}} \mathrm{~S}(j, k)}
$$

where $\mathrm{UA}(i)$ is the spatial weighted mean of UA in root zone from transect $i(i=1,2,3), \operatorname{UA}(i, j, k)$ is the UA of the soil sample from transect $i$, in which $j$ is the horizontal distance from drip emitter and $k$ is the sampling depth to soil surface. 
$\mathrm{S}(j, k)$ is the representative area of the soil sample. The other soil properties in root zone were measured by the same calculation above.

General linear model (GLM) method of Analysis of variance (ANOVA) was used to examine the main effects of planting year $(\mathrm{n}=3)$, horizontal distance from the drip emitter $(n=3)$ and soil depth $(n=4)$ on soil UA in root zone, and differences among transects were tested with Duncan's Multiple Range Test (DMRT). The significance level was $p<0.05$ unless otherwise stated.

A stepwise multiple linear regression option was used to relate UA to soil physicochemical properties. The significance of regression coefficients ( $t$ values) and determination coefficient $\left(\mathrm{R}^{2}\right.$ value) were given for each regression equation.

After calculation of simple correlations coefficients between UA and soil properties, a path analysis was used to estimate the magnitude and significance of causal-relationships from soil physicochemical properties to UA. The direct and indirect path coefficients of each soil physicochemical property to UA were given (Wright, 1934; Bhatt, 1973). Last, the relationship between soil $\mathrm{pH}$ and UA was examined using linear regression analysis.

All the data analyses were conducted by using SPSS 11.5 statistical software (SPSS Inc., Illinois, USA). Figures were created using Surfer 8.0 (Golden Software Inc., Colorado, USA) and SigmaPlot 10.0 (Systat Software Inc. California, USA).

\section{Results}

\subsection{Changes and distributions of UA}

UA in uncultivated soil ranged $1.49-2.26 \mu \mathrm{g} \mathrm{g}^{-1} \mathrm{~h}^{-1}$, with the mean of $1.66 \mu \mathrm{g} \mathrm{g}^{-1} \mathrm{~h}^{-1}$ in $0-40 \mathrm{~cm}$ (Table 1). The soil UA in root zone presented an increasing trend with the planting years. The weighted means were $1.76,2.51$ and $4.32 \mu \mathrm{g} \mathrm{g}^{-1} \mathrm{~h}^{-1}$, respectively in the 3 transects (Table 2), increased by $6.0 \%, 51.2 \%$ and $160.2 \%$, relatively to the uncultivated soil.

A large spatial variability was found within transect. Generally, the farther from the drip emitter, the lower activities of urease were detected. Descriptive statistics of UA for the whole transects showed that the standard error of the mean of observations (SEM) and the standard deviation (SD) increased with increasing planting years (Table. 2).

\subsection{Stepwise multiple regression analysis between $U A$ and soil physicochemical properties}

The $t$ values associated with each variable indicated that only $\mathrm{pH}$ and $\mathrm{C} / \mathrm{N}$ contributed significantly to the variation in $\mathrm{UA}$ in transect 1 , and $\mathrm{R}^{2}$ was only 0.218 . In transect $2, \mathrm{pH}$ and $\mathrm{TN}$ entered into the regression equation and accounted for $45.4 \%$ total variation in $\mathrm{UA}$, while $\mathrm{TP}, \mathrm{pH}$ and moisture entered into the equation in transect 3 , and $64.8 \%$ variation was explained. Based on combined data from all transects, $\mathrm{pH}, \mathrm{TP}, \mathrm{TN}, \mathrm{C} / \mathrm{N}$ and moisture contributed significantly to the variation in UA and accounted for $47.0 \%$ variation in UA (Table 3 ).

\subsection{Path analysis of soil physicochemical properties towards UA}

Significant negative correlations between soil $\mathrm{pH}$ and UA were always found in the 3 and combined transects, with the correlation coefficients of $-0.382,-0.643,-0.689$ and -0.555 respectively $(p<0.05)$ (Table 4$)$. While, the negative correlations between soil ECe and UA never reached the significant level $(p<0.05)$.

Path analysis showed that soil $\mathrm{pH}$ had the largest negative direct path coefficient to UA in transect 1 , and $\mathrm{C} / \mathrm{N}$ had the largest positive. TN and TP had the larger indirect path coefficients through soil $\mathrm{pH}$. In transect 2, the direct effect of $\mathrm{pH}$ was still clearly dominant, with the path coefficient of -0.666 . TP had the positive indirect effect through soil $\mathrm{pH}$. 
Table 2. Descriptive statistics of the soil urease activities from different transects.

\begin{tabular}{cccccccc}
\hline \multirow{2}{*}{ Transects } & \multirow{2}{*}{ Planting years } & Weighted means & \multicolumn{2}{l}{ For the whole transect } & & & \\
\cline { 4 - 8 } & & in root zone* & Minimum & Maximum & Means & SEM & SD \\
\hline 1 & 1 & $1.76 \mathrm{c}$ & 0.68 & 3.18 & 1.56 & 0.06 & 0.45 \\
2 & 2 & $2.51 \mathrm{bc}$ & 0.38 & 3.93 & 1.50 & 0.11 & 0.88 \\
3 & 3 & $4.32 \mathrm{a}$ & 1.37 & 8.53 & 2.70 & 0.17 & 1.37 \\
\hline
\end{tabular}

SEM, the standard error of the mean of observations within each transect. SD, the standard deviation. *Values in this column followed by different letters are significantly different at $p<0.05$.

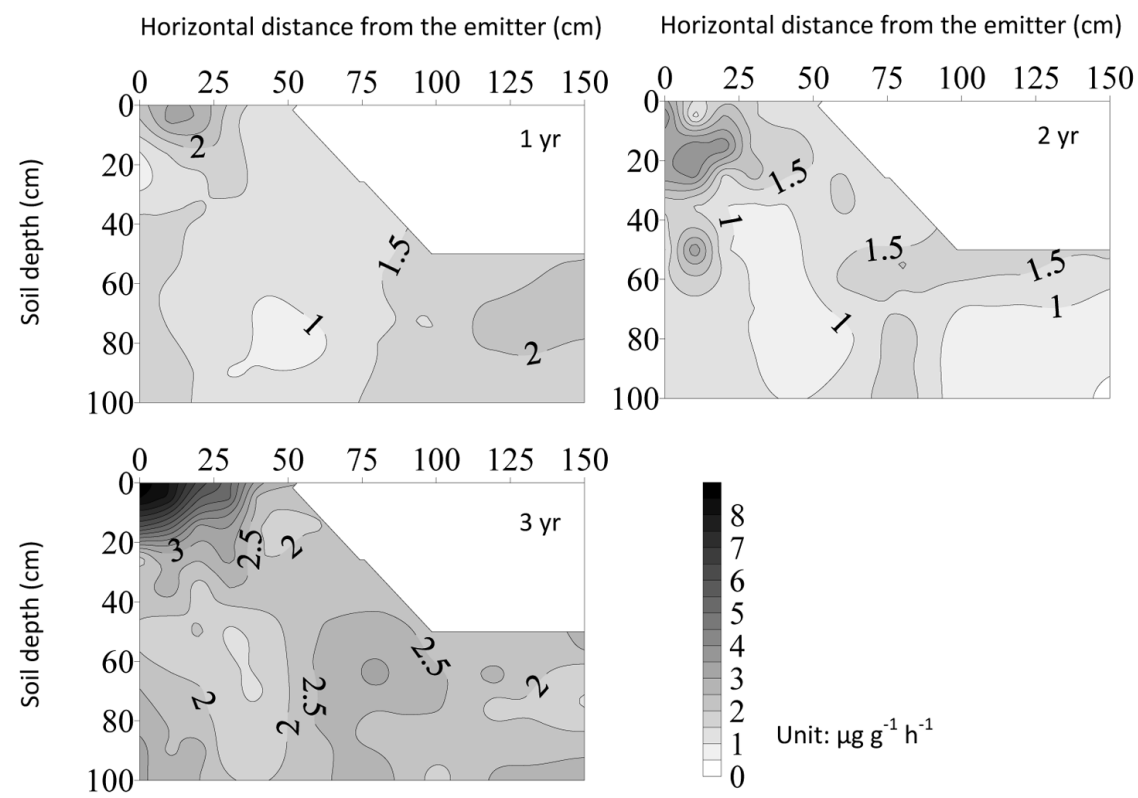

Figure 2. The spatial distribution of urease activities in transects with different planting years

In transect 2 , the direct effect of $\mathrm{pH}$ was still clearly dominant, with the path coefficient of -0.666 . TP had the positive indirect effect through soil $\mathrm{pH}$. In transect 3 , besides the negative direct effect, soil $\mathrm{pH}$ also had considerable negative indirect effect through soil TP and OM (Table 4). Analysis of combined data from 3 transects showed that soil $\mathrm{pH}$ had the largest negative direct path coefficients on UA, while TN and TP had larger positive path coefficients. Soil moisture and TP had positive indirect effects through $\mathrm{pH}$.

With respect to OM, Table 4 also showed a smaller direct path coefficient against UA, and larger indirect path coefficients through soil $\mathrm{pH}, \mathrm{TN}$ and TP. 
Table 3. Stepwise multiple regression equations, significance of regression coefficients, and coefficient of determination $\left(\mathrm{R}^{2}\right)$ for relationship between soil UA and physicochemical properties.

\begin{tabular}{|c|c|c|c|c|c|c|c|c|c|c|c|}
\hline \multirow{2}{*}{ Transects } & \multirow{2}{*}{ Regression equation for $\mathrm{UA}\left(\mu \mathrm{g} \mathrm{g}^{-1} \mathrm{~h}^{-1}\right)$} & \multirow{2}{*}{$\mathrm{N}$} & \multicolumn{8}{|c|}{$t$ values and significance } & \multirow{2}{*}{$\mathrm{R}^{2}$} \\
\hline & & & Moisture & $\mathrm{EC}_{\mathrm{e}}$ & $\mathrm{pH}$ & SAR & $\mathrm{TN}$ & $\mathrm{TP}$ & $\mathrm{OM}$ & $\mathrm{C} / \mathrm{N}$ & \\
\hline 1 & $8.089-0.733 \mathrm{pH}+0.028 \mathrm{C} / \mathrm{N}$ & 62 & NS & NS & $-3.769 * *$ & NS & NS & NS & NS & $2.335^{*}$ & 0.218 \\
\hline 2 & $9.864-0.963 \mathrm{pH}+1.672 \mathrm{TN}$ & 62 & NS & NS & $-4.961 * *$ & NS & $2.106^{*}$ & NS & NS & NS & 0.454 \\
\hline 3 & $10.516+2.581 \mathrm{TP}-0.889 \mathrm{pH}-0.074$ Moisture & 62 & $-2.276^{*}$ & NS & $-3.187 * *$ & NS & NS & $4.103^{* *}$ & NS & NS & 0.648 \\
\hline $1+2+3$ & $8.645-0.893 \mathrm{pH}+1.863 \mathrm{TP}+1.905 \mathrm{TN}+0.038 \mathrm{C} / \mathrm{N}-0.041$ Moisture & 186 & $-3.574 * *$ & NS & $-5.492 * *$ & NS & $5.585^{* *}$ & $4.083^{* *}$ & NS & $3.963^{* *}$ & 0.470 \\
\hline
\end{tabular}

UA, urease activities; *, Significant at $p<0.05$; **, Significant at $p<0.01$; ECe, electrical conductivity of saturated paste extract; $\mathrm{pH}, \mathrm{pH}$ value of saturated paste; $\mathrm{SAR}$, sodium adsorption ratio of the saturated paste extract; TN, total nitrogen; TP, total phosphorus; OM, organic matter; $\mathrm{C} / \mathrm{N}$, ratio of organic carbon-to-total nitrogen; NA, not significant.

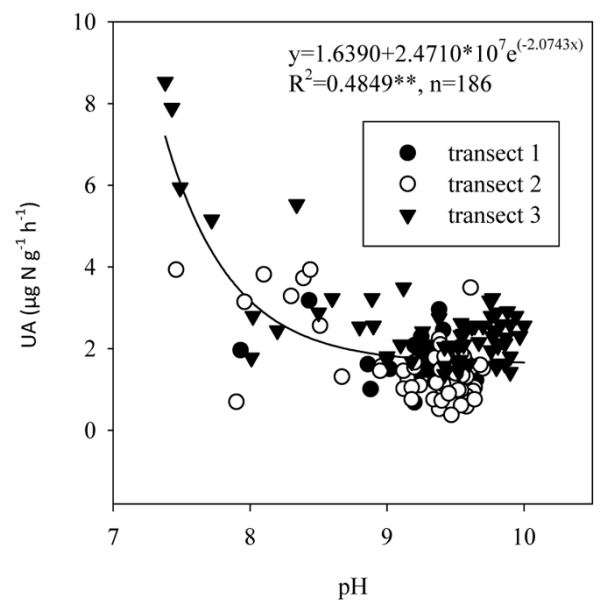

Figure 3. Relationship of soil urease activities (UA) with soil $\mathrm{pH}$. Regression equation, line of best fit and level of statistical significance shown. $* * p<0.01$.

\subsection{Relationship between soil UA and $p H$}

The relationship between soil UA and $\mathrm{pH}$ using combined data from 3 transects is shown in Figure 3. Soil UA decreased generally with increasing $\mathrm{pH}$. The relationship could be expressed by exponential equation $(p<0.01)$.

\section{Discussion}

\subsection{Levels of $U A$}

The magnitudes of UA as observed herein in uncultivated saline-sodic soil were lower than the ranges of values recorded in other soils (Kandeler and Gerber,1988; Tripathi et al., 2006; Yuan et al., 2007), indicating that soil biochemical quality was negatively affected in the saline-sodic soil. Considering the fact that urease originates either from plant shoot litter, living or dead roots, or microorganisms and animal life (Zahir et al., 2001), the reduced UA could be ascribed to the following facts. Firstly, the less enzyme secretion was secreted by the lower populations of soil microorganisms as most of the microorganisms could not survive in the high salinity and sodicity of the soil. Secondly, urease is extracellular, stable and form complexes with the organic and mineral colloids (Garcia and Hernandez, 1996; Tripathi et al., 2006), while salinity induced degradation in arid or semiarid soils is characterized by low soil OM content (Wang et al., 1993; Kaur et al., 2000; Yuan et al., 2007). The average soil OM concentration in the studied soil was only 2.04-6.79 $\mathrm{g} \mathrm{kg}^{-1}$. These low values might be the cause of low microbiological activities. Thirdly, the experimental soil was characterized by excessive $\mathrm{Na}^{+}$, resulting in the high SAR and ESP. In comparison to other cations, $\mathrm{Na}^{+}$has a deleterious effect on soil aggregate stability by increasing clay dispersion (Wang et al., 1993). 
Table 4. Correlation coefficients and path coefficients of soil physicochemical properties (factors) to urease activities.

\begin{tabular}{|c|c|c|c|c|c|c|c|c|c|c|}
\hline \multirow{2}{*}{$\begin{array}{c}\text { Transect } \\
\mathrm{s}\end{array}$} & \multirow{2}{*}{ Factors } & \multirow{2}{*}{$\begin{array}{l}\text { Correlation } \\
\text { coefficients }\end{array}$} & \multicolumn{8}{|c|}{ Path coefficients ${ }^{\mathrm{a}}$} \\
\hline & & & Moisture & $\mathrm{EC}_{\mathrm{e}}$ & $\mathrm{pH}$ & SAR & $\mathrm{TN}$ & $\mathrm{TP}$ & OM & $\mathrm{C} / \mathrm{N}$ \\
\hline \multirow[t]{8}{*}{1} & Moistur & 0.205 & $\underline{0.326}$ & 0.001 & 0.163 & 0.001 & 0.087 & -0.23 & -0.18 & 0.041 \\
\hline & $\mathrm{EC}_{\mathrm{e}}$ & -0.165 & 0.008 & $\underline{0.037}$ & -0.02 & -0.00 & 0.024 & -0.07 & -0.16 & 0.032 \\
\hline & PH & $-0.382 * *$ & -0.123 & 0.002 & $\underline{-0.43}$ & -0.00 & -0.08 & 0.188 & -0.02 & 0.098 \\
\hline & SAR & -0.160 & -0.059 & 0.019 & -0.07 & $\underline{-0.00}$ & -0.05 & -0.02 & -0.00 & 0.041 \\
\hline & $\mathrm{TN}$ & -0.075 & 0.126 & 0.004 & 0.171 & 0.001 & $\underline{0.226}$ & -0.20 & -0.10 & -0.30 \\
\hline & $\mathrm{TP}$ & -0.016 & 0.199 & 0.007 & 0.216 & 0.000 & 0.120 & $\underline{-0.37}$ & -0.06 & -0.112 \\
\hline & $\mathrm{OM}$ & -0.110 & 0.158 & 0.016 & -0.02 & 0.000 & 0.060 & -0.06 & $\underline{-0.37}$ & 0.130 \\
\hline & $\mathrm{C} / \mathrm{N}$ & 0.172 & 0.032 & 0.003 & -0.10 & 0.000 & -0.16 & 0.101 & -0.117 & $\underline{0.418}$ \\
\hline \multirow[t]{8}{*}{2} & Moistur & $0.260^{*}$ & $\underline{0.132}$ & 0.004 & 0.092 & 0.001 & 0.132 & -0.05 & -0.03 & -0.01 \\
\hline & $\mathrm{EC}_{\mathrm{e}}$ & -0.021 & 0.006 & $\underline{0.095}$ & -0.13 & -0.02 & 0.030 & -0.00 & -0.04 & 0.054 \\
\hline & $\mathrm{PH}$ & $-0.643 * *$ & -0.018 & 0.019 & $\underline{-0.66}$ & -0.00 & -0.14 & 0.107 & 0.009 & 0.055 \\
\hline & SAR & -0.076 & -0.006 & 0.071 & -0.16 & $\underline{-0.02}$ & 0.006 & 0.039 & -0.04 & 0.051 \\
\hline & $\mathrm{TN}$ & $0.476^{* *}$ & 0.057 & 0.009 & 0.307 & -0.00 & $\underline{0.307}$ & -0.06 & -0.06 & -0.07 \\
\hline & $\mathrm{TP}$ & 0.228 & 0.032 & 0.002 & 0.345 & 0.005 & 0.094 & $\underline{-0.20}$ & -0.03 & -0.01 \\
\hline & $\mathrm{OM}$ & 0.219 & 0.050 & 0.044 & 0.059 & -0.01 & 0.191 & -0.06 & $\underline{-0.10}$ & 0.055 \\
\hline & $\mathrm{C} / \mathrm{N}$ & -0.184 & -0.009 & 0.030 & -0.21 & -0.00 & -0.13 & 0.014 & -0.03 & $\underline{0.172}$ \\
\hline \multirow[t]{8}{*}{3} & Moistur & 0.163 & $\underline{-0.311}$ & 0.027 & 0.199 & -0.01 & 0.033 & 0.133 & 0.111 & -0.01 \\
\hline & $\mathrm{EC}_{\mathrm{e}}$ & -0.216 & 0.044 & $\underline{-0.19}$ & -0.08 & 0.047 & 0.035 & -0.07 & 0.029 & -0.02 \\
\hline & $\mathrm{PH}$ & $-0.689 * *$ & 0.174 & -0.04 & $\underline{-0.35}$ & 0.014 & -0.00 & -0.36 & -0.116 & 0.005 \\
\hline & SAR & -0.200 & 0.076 & -0.17 & -0.09 & $\underline{0.051}$ & 0.024 & -0.07 & 0.013 & -0.01 \\
\hline & $\mathrm{TN}$ & -0.018 & -0.075 & -0.05 & 0.005 & 0.009 & $\underline{0.135}$ & -0.04 & 0.074 & -0.06 \\
\hline & $\mathrm{TP}$ & $0.764 * *$ & -0.085 & 0.030 & 0.266 & -0.00 & -0.01 & $\underline{0.486}$ & 0.084 & 0.005 \\
\hline & $\mathrm{OM}$ & $0.457 * *$ & -0.212 & -0.03 & 0.255 & 0.004 & 0.062 & 0.251 & $\underline{0.162}$ & -0.03 \\
\hline & $\mathrm{C} / \mathrm{N}$ & 0.087 & 0.039 & 0.030 & -0.01 & -0.00 & -0.07 & 0.018 & -0.03 & $\underline{0.129}$ \\
\hline \multirow[t]{8}{*}{$1+2+3$} & Moistur & 0.040 & $\underline{-0.192}$ & 0.005 & 0.131 & -0.00 & 0.057 & 0.085 & -0.02 & -0.01 \\
\hline & $\mathrm{EC}_{\mathrm{e}}$ & -0.021 & 0.017 & $\underline{-0.06}$ & -0.08 & 0.050 & 0.114 & -0.02 & -0.01 & -0.02 \\
\hline & $\mathrm{PH}$ & $-0.555 * *$ & 0.060 & -0.01 & $\underline{-0.41}$ & 0.015 & -0.04 & -0.20 & 0.019 & 0.030 \\
\hline & SAR & -0.063 & 0.029 & -0.04 & -0.10 & $\underline{0.062}$ & 0.066 & -0.04 & -0.00 & -0.01 \\
\hline & $\mathrm{TN}$ & $0.255^{* *}$ & -0.028 & -0.01 & 0.049 & 0.010 & $\underline{0.390}$ & 0.008 & -0.02 & -0.13 \\
\hline & $\mathrm{TP}$ & $0.514 * *$ & -0.052 & 0.005 & 0.276 & -0.00 & 0.011 & $\underline{0.310}$ & -0.01 & -0.00 \\
\hline & OM & $0.261 * *$ & -0.073 & -0.01 & 0.143 & 0.010 & 0.146 & 0.103 & $\underline{-0.05}$ & 0.004 \\
\hline & $\mathrm{C} / \mathrm{N}$ & 0.029 & 0.012 & 0.005 & -0.04 & -0.00 & -0.19 & -0.00 & -0.00 & $\underline{0.269}$ \\
\hline
\end{tabular}

a, the data with underline are direct path coefficients, and the rests are indirect path coefficients. *, Significant at $p<0.05 ; * *$, Significant at $p<0.01$; ECe, electrical conductivity of saturated paste extract; $\mathrm{pH}, \mathrm{pH}$ value of saturated paste; SAR, sodium adsorption ratio of the saturated paste extract; TN, total nitrogen; TP, total phosphorus; OM, organic matter; $\mathrm{C} / \mathrm{N}$, ratio of organic carbon-to-total nitrogen. 
Garcia et al. (1997) reported that if the soil clays were dispersed by soil salinity, the extracellular enzymes would be less protected and perhaps denatured by proteolysis. Additionally, due to the higher salts concentration in soil, the "salting-out" effect (Tejada et al., 2006), the change in osmotic potential and specific ion toxicities (Rietz and Haynes, 2003) should also be taken into consideration for the reduced UA. The enhanced soil UA is believed to be direct indicator of the improvement of soil fertility, which helps increase $\mathrm{N}$ uptake by plants (Liang et al., 2003; Acosta-Martínez et al., 2007).
In this study, soil UA, particularly in root zone, increased with the planting years (Table 2). The increase should be attributed to the improvement of corresponding soil environment, mainly including salt leaching, decrease of soil $\mathrm{pH}$, and rise in concentrations of nutrients (Table 5). This result coincided partly with that of Speir et al. (1980), who found that UA decreased gradually over 5 months in barren soils, whereas it increased with time in vegetated soils. Plant litter in the soil as well as root exudates provides nitrogenous substrates, which can induce the synthesis of these enzymes in arid soils (Liang et al., 2005).

Table 5. Soil physicochemical properties in root zone.

\begin{tabular}{cccccccccc}
\hline Transects & $\begin{array}{c}\text { Planting } \\
\text { years }\end{array}$ & $\begin{array}{c}\text { Moisture } \\
(\%)\end{array}$ & $\begin{array}{c}\mathrm{EC}_{\mathrm{e}} \\
\left(\mathrm{dS} \mathrm{m}^{-1}\right)\end{array}$ & $\mathrm{pH}$ & $\begin{array}{c}\mathrm{SAR} \\
\left(\mathrm{mmol} \mathrm{L}^{-1}\right)^{0.5}\end{array}$ & $\begin{array}{c}\mathrm{TN} \\
\left(\mathrm{g} \mathrm{kg}^{-1}\right)\end{array}$ & $\begin{array}{c}\mathrm{TP} \\
\left(\mathrm{g} \mathrm{kg}^{-1}\right)\end{array}$ & $\begin{array}{c}\mathrm{OM} \\
\left(\mathrm{g} \mathrm{kg}^{-1}\right)\end{array}$ & $\mathrm{C} / \mathrm{N}$ \\
\hline $0^{\mathrm{a}}$ & 0 & 9.82 & 10.26 & 9.38 & 38.88 & 0.31 & 0.70 & 6.09 & 10.08 \\
$1^{\mathrm{b}}$ & 1 & 27.75 & 7.31 & 9.04 & 10.96 & 0.38 & 0.77 & 6.51 & 10.93 \\
$2^{\mathrm{b}}$ & 2 & 26.01 & 7.18 & 8.38 & 10.16 & 0.47 & 0.86 & 6.32 & 6.74 \\
$3^{\mathrm{b}}$ & 3 & 21.79 & 5.15 & 8.08 & 7.19 & 0.51 & 1.03 & 7.58 & 9.16 \\
\hline
\end{tabular}

Note: $a$, data in this low were calculated as the depth weighted mean of $0-40 \mathrm{~cm}$ in uncultivated soil; $\mathrm{b}$, data in this law were calculated as the spatial weighted mean in root zone. ECe, electrical conductivity of saturated paste extract; $\mathrm{pH}, \mathrm{pH}$ value of saturated paste; SAR, sodium adsorption ratio of the saturated paste extract; TN, total nitrogen; TP, total phosphorus; OM, organic matter; $\mathrm{C} / \mathrm{N}$, ratio of organic carbon-to-total nitrogen.

All soil UA revealed large within-transect variability (Table 2, Figure 2). The main reason for this was the changes of micro-area environment induced by drip irrigation, where small difference in the position from the drip emitter could cause strong variability in salt accumulation and fertilizer level (Liu et al., 2011; Zhang et al., 2013), and consequently differences in the growth of plant roots and soil microorganisms.

It was also found that the substantial enzyme activities could persist even at high soil salinity and sodicity, which was supported by Rietz and Haynes (2003). Indeed, Zahran (1997) noted that the production and activity of enzymes from the saline soil bacteria had greater salt requirements than those of corresponding enzymes from non-saline bacteria.

\subsection{Relationships between UA and soil properties}

In order to relate soil properties to UA, stepwise multiple regression analyses were performed on data compiled from each transect, and on combined data 
from all transects. In transect 1 , only $21.8 \%$ variation in UA was accounted for by the regression equation, which included soil $\mathrm{pH}$ and $\mathrm{C} / \mathrm{N}$. This suggested that although variations in soil $\mathrm{pH}$ and $\mathrm{C} / \mathrm{N}$ were important in predicting UA, there remained other determining variables not involved in this study, and the similar result was reported by Cookson (1999). The increase in $\mathrm{R}^{2}$ and grow in number of factors entered into the regression equations indicted that $\mathrm{UA}$ in saline-sodic soils became more predictable during the amelioration. This could also be proved by the correlation analysis, which showed that the number of soil properties significantly correlated with UA increased with planting years (Table 4). Cookson (1999) reported that in non-saline soils, the UA was closely associated with several soil properties, whereas at saline conditions, it was only significantly associated with soil salinity.

As a straightforward extension of multiple regression, path analysis has been applied in quite a variety of cases to estimate the magnitude and significance of hypothesized causal connections among variables (Ball et al., 2001). Direct path coefficients implied that soil $\mathrm{pH}$ values had a negative effect on UA. Although a significant positive correlation existed between soil $\mathrm{OM}$ and UA in transect 3 and in combined transects, $\mathrm{OM}$ never entered into stepwise regression equations (Table 3) and the direct path coefficients of soil OM to UA were also relatively smaller (Table 4). Soil OM influenced UA mainly through other factors such as soil $\mathrm{pH}$ and $\mathrm{TN}$, which was indicated by the indirect path coefficients.

Both stepwise regression and path analysis showed that soil $\mathrm{pH}$ had a dominant effect on $\mathrm{UA}$, so soil $\mathrm{pH}$ was chosen solely for the linear regression against UA. And enzyme activity has been suggested to be used to assess soil $\mathrm{pH}$ because of its sensitivity to soil pH (Guan, 1986). Soil samples in this study, coming from different plots and different positions from the drip emitter, had a wide gradient of soil salinity and sodicity. The range of soil $\mathrm{pH}$ in present study, from 7.38 to 10.00 , represented almost the entire range of alkalinity observed in cultivated salt-affected soils of arid/semi-arid regions, northwest China (Wang et al., 1993). The exponential relationship between soil UA and $\mathrm{pH}$ demonstrated the highly detrimental effect that small increase in soil $\mathrm{pH}$ exerted on soil $\mathrm{UA}$, especially in the low $\mathrm{pH}$ section, a small increase in soil $\mathrm{pH}$ could trigger great decrease in UA, which was more evident for transect 3 . While at high $\mathrm{pH}$ section, the UA was not so sensitive to the changes in $\mathrm{pH}$, possibly because of the extremely low UA level in high soil $\mathrm{pH}$. High soil $\mathrm{pH}$ affects availability of nutrients, and controls the composition and diversity of the microbial community (Dick et al., 2000). Moreover, soil $\mathrm{pH}$ had significant negative effects on soil organic matter, as reported by Muhammad et al. (2008). The low content of soil organic matter may make the enzyme more prone to denaturation and biological degradation by soil humic polymers (Baligar et al., 1991; Zahir et al., 2001), and also create an unsuitable substrate for the development of soil microbial.

\section{Conclusions}

Urease presented a lower activity in the uncultivated saline-sodic soils in Ningxia Plain, northwest China. Drip irrigation-induced changes of salinity and sodicity greatly affected soil microbial and biochemical properties, reflected by the increase in UA. With an increase of planting years, the significances of multivariate correlations between UA and soil properties increased gradually. Among the 8 soil properties studied, soil $\mathrm{pH}$ was the only factor that could significantly affect the soil UA in the first planting year. Nevertheless, after 3 planting years, soil UA could be predicted by interactions of several soil properties. Path analysis indicated that $\mathrm{pH}$ had a larger negative direct effect on UA, and the relationships between UA and soil $\mathrm{pH}$ showed that a small increase in soil $\mathrm{pH}$ could exert a highly detrimental effect on UA. 


\section{Acknowledgements}

This study was supported by the Action Plan for the Development of Western China of the Chinese Academy of Sciences (Grant No. KZCX2-XB3-16), the National High Technology R \& D Program of China (Grant No. 2013BAC02B02 and 2013BAC02B01), and the Agricultural Comprehensive Development Projects of Ningxia (Grant No. NTKJ-2014-01).

\section{References}

Abrol, I.P., Yadav, J.S.P., Massoud, F.I. 1988. Saltaffected soils and their management. FAO soils bulletin 39. FAO, Rome, 2-4 p.

Acosta-Martínez, V., Cruz, L., Sotomayor-Ramírez, D., Pérez-Alegría, L. 2007. Enzyme activities as affected by soil properties and land use in a tropical watershed. Appl. Soil Ecol. 35, 35-45.

Baligar, V.C., Staley, T.E., Wright, R.J. 1991. Enzyme activities in Appalachian soils: 2. Urease. Commu. Soil Sci. Plant Anal. 22, 315-322.

Ball, R.A., Mcnew, R.W., Vories, E.D., Keisling, T.C., Purcell, L.C. 2001. Path analyses of population density effects on short-season soybean yield. Agron. J. 93, 187-195.

Bao, S.D. 2000. Soil agrochemical analysis. China Agricultural Press, Beijing, 25-114 p.

Bhatt, G.M. 1973. Significance of path coefficient analysis in association. Euphytica. 22, 338-343.

Burt, C.M., Isbell, B. 2005. Leaching of accumulated soil salinity under drip irrigation. Trans. ASAE. 48, 2115-2121.

Cookson, P., Lepiece, A.G. 1996. Urease enzyme activities in soils of the Batinah region of the Sultanate of Oman. J. Arid Environ. 32, 225-238.
Cookson. P. 1999. Spatial variation of soil urease activity around irrigated date palms. Arid Soil Res. Rehab. 13, 155-169.

Dick, W.A., Cheng, L., Wang, P. 2000. Soil acid and alkaline phosphatase activity as $\mathrm{pH}$ adjustment indicators. Soil Biol. Biochem. 32, 1915-1919.

Garcia, C., Hernandez, T. 1996. Influence of salinity on the biological and biochemical activity of a calciothid soil. Plant Soil. 178, 255-263.

Garcia, C., Hernandez, T., Costa, F. 1997. Potential use of dehydrogenase activity as an index of microbial activity in degraded soils. Commu. Soil Sci. Plant Anal. 28, 123-134.

Guan, S.Y. 1986. Soil enzymes and their research methods. Agricultural Press, Beijing, 273-339 p.

Hanson B., May, D. 2003. Drip irrigation increases tomato yields in salt-affected soil of San Joaquin Valley. California Agriculture. 57, 132-137.

IUSS Working Group WRB. 2007. World Reference Base for Soil Resources 2006, first update 2007. World Soil Resources Reports No. 103. FAO, Rome, 49 p.

Kandeler, E., Gerber, H. 1988. Short-term assay of soil urease activity using colorimetric determination of ammonium. Biol. Fertil. Soils. 6, 68-72.

Kaur, B., Gupta, S.R., Singh, G. 2000. Soil carbon, microbial activity and nitrogen availability in agroforestry systems on moderately alkaline soils in northern India. Appl. Soil Ecol. 15, 283-294.

Liang, Y.C., Yang, Y.F., Yang, C.G., Shen, Q.R., Zhou, J.M., Yang, L.Z. 2003. Soil enzymatic activity and growth of rice and barley as influenced by organic manure in an anthropogenic soil. Geoderma. 115, 149-160. 
Liang, Y.C., Si, J., Nikolic, M., Peng, Y., Chen, W., Jiang, Y. 2005. Organic manure stimulates biological activity and barley growth in soil subject to secondary salinization. Soil Biol. Biochem. 37, 1185-1195.

Liu, S., Kang, Y., Wan, S., Wang, Z., Liang, Z., Sun, J. 2011. Water and salt regulation and its effects on Leymus chinensis growth under drip irrigation in saline-sodic soils of the Songnen Plain. Agric. Water Manage. 98, 1469-1476.

Muhammad, S., Muller, T., Joergensen, R.G. 2008. Relationships between soil biological and other soil properties in saline and alkaline arable soils from the Pakistani Punjab. J. Arid Environ. 72, 448-457.

Qadir, M., Schubert, S., Ghafoor, A., Murtaza, G. 2001. Amelioration strategies for sodic soils: a review. Land Degrad. Develop. 12, 357-386.

Rietz, D.N., Haynes, R.J. 2003. Effects of irrigationinduced salinity and sodicity on soil microbial activity. Soil Biol. Biochem. 35, 845-854.

Sinsabaugh, R.L. 1994. Enzymatic analysis of microbial pattern and process. Biol. Fertil. Soils. $17,69-74$

Speir, T.W., Lee, R., Pansier, E.A., Cairns, A. 1980. A comparison of sulphatase, urease and protease activities in planted and fallow soils. Soil Biol. Biochem. 12, 281-291.

Tejada, M., Garcia, C., Gonzalez, J.L., Hernandez, M.T. 2006. Use of organic amendment as a strategy for saline soil remediation: Influence on the physical, chemical and biological properties of soil. Soil Biol. Biochem. 38, 1413-1421.
Tripathi, S., Kumari, S., Chakraborty, A., Gupta, A., Chakrabarti, K., Bandyapadhyay, B.K. 2006. Microbial biomass and its activities in salt-affected coastal soils. Biol. Fertil. Soils. 42, 273-277.

Wang, J.Z. 1990. Soils in Ningxia. Ningxia People's Press, Yinchuan, 89-120 p

Wang, Z.Q., Zhu, S.Q., Yu, R.P., Li, L.Q., Shan, G.Z., You, W.R., Zeng, X.X., Zhang, C.W., Zhang, L.J., Song, R.H. 1993. Salt Affected Soils in China. Science press, Beijing, 215-249 p.

Wright, S. 1934. The method of path coefficients. The Annals of Mathematical Statistic. 5, 161-215.

Yuan, L., Huang, J., Yu, S. 1997. Responses of nitrogen and related enzyme activities to fertilization in rhizosphere of wheat. Pedosphere. 7, 141-148.

Yuan, B.C., Li, Z.Z., Liu, H., Gao, M., Zhang, Y.Y. 2007. Microbial biomass and activity in salt affected soils under arid conditions. Appl. Soil Ecol. 35, 319-328.

Zahir, A.Z., Muhammad, A.R.M., Muhammad, A. 2001. Soil Enzymes Research: A Review. J. Biol. Sci. 1, 299-307.

Zahran, H.H. 1997. Diversity, adaptation and activity of the bacterial flora in saline environments. Biol. Fertil. Soils. 25, 211-223.

Zhang, T., Kang, Y., Wan, S. 2013. Shallow sand-filled niches beneath drip emitters made reclamation of an impermeable saline-sodic soil possible while cropping with Lycium barbarum L. Agric. Water Manage. 119, 54-64. 